\title{
Damage by Acromyrmex spp. to an Initial Pinus taeda L. Planting
}

\author{
Edison Bisognin Cantarelli ${ }^{1}$ (D), Ervandil Corrêa Costa ${ }^{2}$ (D), \\ Raúl Vicente Pezzutti ${ }^{3}\left(0\right.$, Ronald Zanetti $^{4}\left(\mathbb{0}\right.$, Marciane Danniela Fleck $^{2}$ () \\ ${ }^{1}$ Universidade Federal de Santa Maria (UFSM), Frederico Westphalen, RS, Brasil \\ ${ }^{2}$ Universidade Federal de Santa Maria (UFSM), Santa Maria, RS, Brasil \\ ${ }^{3}$ Forestal Bosques del Plata S.A., Posadas, Misiones, Argentina \\ ${ }^{4}$ Universidade Federal de Lavras (UFLA), Lavras, MG, Brasil
}

\begin{abstract}
The objective of this study is to evaluate the damage caused by Acromyrmex heyeri Forel, 1899 and Acromyrmex lobicornis Emery, 1887 to Pinus taeda L. seedlings during the first two months after replanting. The experiment was conducted in the company Bosques del Plata, located in the province of Corrientes, Argentina. The evaluations were carried out at seven, 14, 21, 36, 50 and 65 days after replanting the seedlings, when the number of dead, alive, non-attacked, alive deneedled, and alive deneedled with cuts/damage to the apical bud by leaf-cutting ants was quantified. The results allow us to conclude that $A$. heyeri and A. lobicornis are responsible for losses to the order of $20.8 \%$ of the seedlings in an initial $P$. taeda stand at 65 days. The damage caused to seedlings by the two leaf-cutting ant species is constant over time, in which A. lobicornis is more voracious than $A$. heyeri.
\end{abstract}

Keywords: Acromyrmex heyeri, Acromyrmex lobicornis, leaf-cutting ants, forest pests. 


\section{INTRODUCTION AND OBJECTIVES}

The area planted with species of the Pinus genus in the province of Corrientes, Argentina, reached 312,369.05 hectares in 2015 (Elizondo, 2015) and the most used species in forest plantations in the region is Pinus taeda L. (Pezzutti et al., 2016). Among the silvicultural problems of the forests planted with Pinus, leaf-cutting ants of the Atta and Acromyrmex genus stand out, reaching the level of pest due to the magnitude of the damage they cause to forest plantations (Nickele et al., 2009).

The damage is due to the fact that leaf-cutting ants use fresh vegetable substrates to grow a fungus from which they feed on. Thus, these ants stand out economically as they are harmful to agroforestry systems, affecting a wide variety of plant species that are cultivated by man (Della Lucia, 2011).

The economic losses caused by leaf-cutting ants in forest plantations are higher between the first and third years of age. The losses caused by these insects in the first months may be irreversible, since the seedlings are fragile and easily damaged (Vasconcelos \& Cherrett, 1997). The damage caused by leaf-cutting ants can also decrease the resistance of the plants, which become more susceptible to attacks by other insects (Cantarelli et al., 2008).

Among the damage caused to $P$. taeda seedlings by leaf-cutting ants, the loss in growth in height and diameter stands out, which may be irreversible depending on the attack intensity. Thus, the intensity of leaf-cutting ants occurrence in $P$. taeda seedlings is extremely important, because not all attacks necessarily result in damage to plants (Nickele, Reis Filho et al., 2012).

In a study carried out in São Mateus do Sul, PR, Nickele, Reis Filho et al. (2012) found that artificial defoliation does not cause losses in height and diameter growth of $P$. taeda plants with less than $75 \%$ defoliation; however, there are losses in height and diameter growth of plants with $100 \%$ defoliation, regardless of the apical meristem being cut and of the death of some plants. Between the diameter and height of $P$. taeda plants at one month of age, defoliation with greater than $50 \%$ intensity affects the diameter more than the height of the plants (Reis Filho, Santos et al., 2011).
In this study, an evaluation of the losses of $P$. taeda seedlings caused by ants of Acromyrmex genus was prioritized to the detriment of Atta, since it was verified in previous samplings that species of this genus comprise $98 \%$ of the anthills existing in the planting areas of the company, and the data collection location.

In this sense, this study aims to evaluate the damage caused by Acromyrmex heyeri Forel, 1899 and Acromyrmex lobicornis Emery, 1887 to Pinus taeda L. seedlings during the first two months after replanting in Corrientes, Argentina.

\section{MATERIALS AND METHODS}

An implantation area of 2.8 hectares located in "Jesus Cue" was analyzed to evaluate the damage of leaf-cutting ants. This area is at an altitude of $107.5 \mathrm{~m}$, between the geographic coordinates $27^{\circ} 54^{\prime} 58^{\prime \prime}$ latitude South and $56^{\circ} 07^{\prime} 22^{\prime \prime}$ longitude West, in the province of Corrientes, Argentina. It presented the same characteristics of most of the planting sites of Bosques del Plata company, which are low and flat areas with a predominant grassy vegetation of the Paspalum genus (Poaceae) (90\%) and some eudicotyledons.

The climate in the study region is Cfa according to the Köppen climate classification, mesothermic, with hot summers. The region has no dry season and the highest rainfall volumes are recorded in the fall. The annual average temperature is $20.5^{\circ} \mathrm{C}$ and the average annual rainfall is $1,867 \mathrm{~mm}$ (Pezzutti \& Caldato, 2011).

Twenty anthills were initially found in the study area three months before planting, all of them belonging to the Acromyrmex genus. Afterwards, the soil was subsoiled only in the planting line (1.0 m width), thus maintaining the original vegetation in most of the area. A new survey found that the soil preparation influenced eight anthills of Acromyrmex spp., which had initially existed there, to abandon the area. Thus, only 12 of the remaining anthills of the Acromyrmex genus were georeferenced with GPS, measured and samples were collected for later identification at the Phytosanitary Department "Eliseu Maciel" Faculty of Agronomy, UFPel under the care of Prof. Dr. Alci Enimar Loeck (Table 1).

After preparation of the soil, 3,812 P. taeda seedlings were planted, measuring between $3 \mathrm{~mm}$ and $4 \mathrm{~mm}$ of stem diameter and an average of $30 \mathrm{~cm}$ 
Table 1. Ant species, diameter and location of each anthill analyzed in the study. Corrientes - Argentina.

\begin{tabular}{lcc}
\multicolumn{1}{c}{ Species } & $\begin{array}{c}\text { Diameter of the anthill } \\
\text { base }(\mathbf{c m})\end{array}$ & Location (South/West) \\
\hline $1-$ Acromyrmex heyeri & 80.0 & $27^{\circ} 54^{\prime} 32.2^{\prime \prime} 56^{\circ} 11^{\prime} 06.3^{\prime \prime}$ \\
\hline $2-$ Acromyrmex heyeri & 60.0 & $27^{\circ} 54^{\prime} 32.9^{\prime \prime} 56^{\circ} 11^{\prime} 07.0^{\prime \prime}$ \\
\hline $3-$ Acromyrmex heyeri & 60.0 & $27^{\circ} 54^{\prime} 32.6^{\prime \prime} 56^{\circ} 11^{\prime} 07.9^{\prime \prime}$ \\
\hline $4-$ Acromyrmex lobicornis & 90.0 & $27^{\circ} 54^{\prime} 33.2^{\prime \prime} 56^{\circ} 11^{\prime} 09.4^{\prime \prime}$ \\
$5-$ Acromyrmex lobicornis & 70.0 & $27^{\circ} 54^{\prime} 34.5^{\prime \prime} 56^{\circ} 11^{\prime} 10.8^{\prime \prime}$ \\
$6-$ Acromyrmex lobicornis & 60.0 & $27^{\circ} 54^{\prime} 32.4^{\prime \prime} 56^{\circ} 11^{\prime} 09.3^{\prime \prime}$ \\
\hline $7-$ Acromyrmex lobicornis & 50.0 & $27^{\circ} 54^{\prime} 34.2^{\prime \prime} 56^{\circ} 11^{\prime} 08.3^{\prime \prime}$ \\
\hline $8-$ Acromyrmex heyeri & 60.0 & $27^{\circ} 54^{\prime} 31.1^{\prime \prime} 56^{\circ} 11^{\prime} 07.3^{\prime \prime}$ \\
$9-$ Acromyrmex heyeri & 80.0 & $27^{\circ} 54^{\prime} 32.0^{\prime \prime} 56^{\circ} 11^{\prime} 12.9^{\prime \prime}$ \\
$10-$ Acromyrmex heyeri & 70.0 & $27^{\circ} 54^{\prime} 29.5^{\prime \prime} 56^{\circ} 11^{\prime} 08.7^{\prime \prime}$ \\
$11-$ Acromyrmex heyeri & 50.0 & $27^{\circ} 54^{\prime} 29.3^{\prime \prime} 56^{\circ} 11^{\prime} 07.9^{\prime \prime}$ \\
$12-$ Acromyrmex heyeri & $27^{\circ} 54^{\prime} 28.2^{\prime \prime} 56^{\circ} 11^{\prime} 07.3^{\prime \prime}$ \\
\hline
\end{tabular}

in height, at a spacing of $1.75 \mathrm{~m}$ between seedlings and $4 \mathrm{~m}$ between rows, totaling 1,428 seedlings/ha. The replanting was carried out 73 days after planting the seedlings that were damaged due to adverse factors not caused by leaf-cutting ants. No previous control of leaf-cutting ants was implemented in the area.

The evaluations of leaf-cutting ants damages were carried out at seven, 14, 21, 36, 50 and 65 days after replanting the seedlings, when the number of dead, alive, non-attacked, alive deneedled and alive deneedled deciduous leaves with cuts/damage to the apical bud was determined by leaf-cutting ants. As the ants were randomly distributed in the area, the adopted procedure for evaluation was to count all the seedlings in each line of the planting.

A map was generated for each time evaluation at the referred days after replanting the seedlings with the location of the attacked seedlings and the anthills, thus being able to analyze how many seedlings were attacked by anthill and the distance that the ants of each anthill traveled.

Throughout the 65 days of evaluation, the foraging of the two leaf-cutting ants' species, previously identified by the abovementioned specialist, was visualized daily to monitor which seedlings were attacked by each anthill. The visualization methodology was carried out by observing the foraging path and thus identifying each seedling that was attacked by the ants of each specific anthill. This survey was carried out by eight people who performed the visualizations in the field with observation beginning in the morning and continuing for basically the whole day.

The average number of $P$. taed $a$ seedlings attacked (with or without cut of the apical bud) by the Acromyrmex genus ants in the evaluations carried out at seven, 14, 21, 36, 50 and 65 days after replanting the seedlings was represented graphically over time, with the time evaluations on the abscissae axis and the accumulated average number of attacked $P$. taed $a$ seedlings by the two species of leaf-cutting ants on the ordinates axis. These data from the accumulated mean number of attacked $P$. taeda seedlings were transformed into the formula $\sqrt{ }(\mathrm{x}+0.5)$ to meet the normality assumptions of the residues using the Kolmogorov-Smirnov test and homogeneity of variances by the Bartlett test to determine the analysis of variance and then obtain the degree of significant polynomial.

The mean ( \pm standard deviation) of the accumulated number of $P$. taeda deneedled seedlings (DCC) and without cut/damage to the apical bud (DSC), respectively, by leaf-cutting ants after 65 days of evaluation were statistically analyzed using the SAS program (Statistical Analysis System) and submitted to the T-test for the comparison of means at a $5 \%$ error probability level in order to verify the difference in attack intensity between the A. heyeri and A. lobicornis species. 


\section{RESULTS AND DISCUSSION}

After 65 days of evaluation, 2,987 seedlings (78.4\%) of the total of 3,812 P. taeda seedlings planted in the area were recorded, alive and not attacked by leaf-cutting ants; 795 seedlings (20.8\%) were alive deneedled with or without cutting/damage to the apical bud by the ants of 12 anthills; and 30 seedlings $(0.8 \%)$ were dead due to other factors. This result represents an average of 66.25 seedlings attacked by anthill, considering the two species of leaf-cutting ants.

Among the 795 alive deneedled seedlings after 65 days of evaluation, 507 seedlings had cuts/damage to the apical bud, representing $63.8 \%$, while 288 seedlings (36.2\%) were only deneedled with no cuts/ damage to the apical bud by the two species of leafcutting ants. This damage can be easily recognizable in the field, as emphasized by Reis Filho et al. (2007), since the attack of Acromyrmex genus ants in Pinus plantations is characterized by cuts to part or all of the needles and also by the destruction/elimination of the apical part of the plants.

The results evidenced the damage that leaf-cutting ants can cause in seedlings in the first year of planting, as emphasized in the work of Cantarelli et al. (2008), in which the authors found that there is a significant reduction in the development of $P$. taeda seedlings when attacked by leaf-cutting ants of Acromyrmex genus in the first 24 months of age, and subsequent attacks are not significantly detrimental to the development of plants.

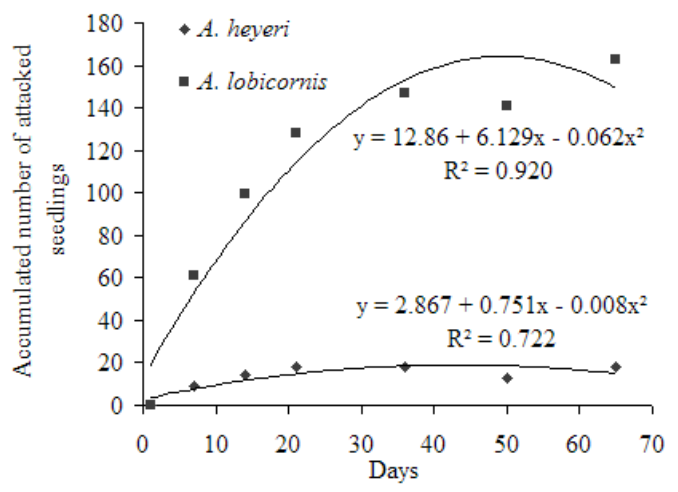

Figure 1. Average accumulated number of Pinus taeda seedlings attacked by Acromyrmex genus ants in the period of 65 days after replanting (with or without cuts to the apical bud). Corrientes, Argentina. y: dependent variable; $\mathrm{x}$ : independent variable; $\mathrm{R}^{2}$ : determination coefficient.
Analyzing the herbivory by species in a visual way in the field, it was verified that 652 (82\%) seedlings were attacked (deneedled with or without cuts to the apical bud) by workers from four A. lobicornis anthills, while $143(18 \%)$ seedlings were attacked by workers from eight $A$. heyeri anthills. This represents an average of 163 seedlings attacked by anthills of the first species at 65 days or 2.5 seedlings/day. On the other hand, A. heyeri damaged an average of 18 seedlings per anthill at 65 days or 0.28 seedlings/day. This difference corresponds to nine times more voracity by $A$. lobicornis compared to A. heyeri (Figure 1).

Information about the foraging of $A$. heyer $i$ is scarce (Loeck \& Grürzmacher, 2001) and only report that their colonies are found in areas of degraded natural pastures (Gecko \& Loeck, 1999; Loeck \& Grürzmacher, 2001), and present preference for foraging grasses, but in the absence of grass, they cut plants from several other families (Diehl-Fleig \& Droste, 1992; Loeck \& Grürzmacher, 2001; Zolessi \& Abenante, 1998).

The evaluations in the time did not present significant interaction with the studied variables, indicating that the ants' attack on the seedlings after replanting was constant and of equal intensity. There was a significant difference between ant species in the number of seedlings deneedled with cuts/damage to the apical bud, but not in the number of deneedled seedlings without cuts/damage to the apical bud at 65 days of evaluation. A. lobicornis caused this damage in more seedlings than $A$. heyeri, demonstrating that the latter species is less voracious to $P$. taeda in the region of Corrientes, Argentina (Table 2).

In northern Patagonia, Argentina, Pérez et al. (2011) found that more than $50 \%$ of Pinus contorta Douglas ex Loudon needles were damaged by A. lobicornis, as well as the complete deneedling of some seedlings, which evidences the voracity of the species.

Verifying the natural attack of $A$. crassispinus on initial P. taeda stands without control for ants, Nickele, Reis Filho et al. (2012) found that the attack was higher in the first months after planting, being more intense during the first 30 days; subsequent evaluations showed that the percentage of attacked plants decreased at all evaluated defoliation levels. The authors emphasized that this could be attributed to the fact that the ants had no other option in the first month of foraging after planting, since there was no native vegetation 
Table 2. Number of evaluations and mean ( \pm standard deviation) of the number of accumulated Pinus taeda seedlings deneedled with cuts/damage and without cuts/damage to the apical bud, respectively, by leaf-cutting ants after 65 days of evaluation. Corrientes, Argentina.

\begin{tabular}{|c|c|c|c|}
\hline \multirow{2}{*}{ Species } & \multirow{2}{*}{$\mathbf{N}$} & \multicolumn{2}{|c|}{ Mean number of seedlings } \\
\hline & & DCC & DSC \\
\hline Acromyrmex heyeri & 6 & $13.33( \pm 14.26) \mathrm{b}$ & $103.83( \pm 29.30) \mathrm{a}$ \\
\hline Acromyrmex lobicornis & 6 & $248.16( \pm 128.09) \mathrm{a}$ & $226.83( \pm 146.57) \mathrm{a}$ \\
\hline
\end{tabular}

N: number of evaluations; DCC: Pinus taeda seedlings deneedled with cuts/damage to the apical bud; DSC: Pinus taeda seedlings deneedled without cuts/damage to the apical bud. Means not followed by the same letter in the column differ by the t-test at the $5 \%$ probability level of error.

between the planting lines due to the soil preparation for planting the seedlings.

Thus, when native vegetation between planting lines is not competitive with cultivated plants, it should be maintained as it provides food and cover for various species from natural enemies and other types of plants which serve as substrate for the cultivated fungus by leaf-cutting ants (Araújo et al., 2003).

In the southern plateau of Santa Catarina (SC), in Anita Garibaldi, Buratto et al. (2012) evaluated the damage caused by $A$. crassispinus and A. heyeri leaf-cutting ants to $P$. taeda plantations and found that the total mean value of plants attacked by ants at all defoliation levels through the whole evaluation period (63 days) was 86 seedlings per hectare, corresponding to a mean total percentage of $5.38 \%$ of damaged plants per hectare. The authors also verified that the most intense attack was at 35 days after planting, when the ants cut all the seedlings' needles, leaving only the apical meristem.

In Vargem Bonita, SC, Vitorino et al. (2015) evaluated the damage caused by Acromyrmex spp. to seedlings with minimum cuts to the needles of seedlings until presenting total withdrawal of the needles and cuts to the apical bud in experiments with the use of the active ingredient imidacloprid. In relation to the damage in the first evaluation at 25 days after the experiment installation, from the total of 1,600 seedlings, 11 were damaged by leaf-cutting ants $(0.69 \%)$. In the second evaluation after 56 days, 29 seedlings (1.81\%) were attacked; and in the last evaluation 81 days after the experiment installation, 65 seedlings (4.06\%) presented damage.

Analyzing the maps of each evaluation, it was verified that the forage distance from the anthill varied greatly, being able to reach $100 \mathrm{~m}$. This result corroborates that of Hölldobler \& Wilson (1990), who point out that the distance traveled by ants to forage plants usually extends more than $100 \mathrm{~m}$ from the nest.

These long foraging distances would be easily explained if plant material were not available in the vicinity of the nest, but there were changes close to the nest and were often little affected by leaf-cutting ants. One hypothesis is that the workers defined a foraging area with the native plants (grasses and eudicotyledons) and as soon as this material was exhausted, the nearest P. taeda seedlings were cut.

Another hypothesis is that due to the competition with the neighbors, the workers seek to define broad areas for foraging in order to ensure plant material for their development. This was emphasized by Nickele, Pie et al. (2012), who analyzed a colony of $A$. heyeri which emigrated $47.5 \mathrm{~m}$ away from its original nest to a new location, probably because it suffered considerable stress due to competitive interactions with a $A$. crassispinus colony.

Another aspect observed in the field was the attack sequence. There were around four to ten seedlings attacked in the same planting line and one plant between them without being attacked. What would cause these workers to cut one plant and not another? The most likely hypothesis is that the composition of this $P$. taeda seedling could have secondary toxic compounds to fungi or ants.

Other factors, such as physical characteristics of the plant, are unlikely because they are seedlings with a very similar phenotype. The possibility of more valuable areas for foraging is unlikely, since the vegetation type and the topographic conditions of the study area are similar.

One last observation is that the attack sequence occurred in the planting line, either because of the ease of movement due to the path being clean because the 
soil preparation was performed in the planting line, or because the seedlings were closer in line than in the middle. However, Reis Filho, Iede et al. (2011) emphasize that cleaning the area should only be carried out in the planting lines in order to avoid Pinus spp. seedlings becoming the only foraging sources.

\section{CONCLUSIONS}

The ants of the A. heyeri and A. lobicornis species damage $P$. taeda seedlings in the first two months after replanting.

The damage caused to the seedlings by the two species of leaf-cutting ants is of different intensity, and $A$. lobicornis has a more severe attack intensity.

The damage intensity by the leaf-cutting ants does not vary over time, meaning that the damage to the seedlings by these ants is constant and of equal intensity.

\section{ACKNOWLEDGMENTS}

The authors thank the company Bosques del Plata S.A., from Corrientes, Argentina, for the area of study.

\section{SUBMISSION STATUS}

Received: 16 Feb., 2016

Accepted: 26 Aug., 2018

\section{CORRESPONDENCE TO}

\section{Edison Bisognin Cantarelli}

Universidade Federal de Santa Maria (UFSM), campus de Frederico Westphalen, Linha Sete de Setembro, s/n, BR 386 Km 40, CEP 98400-000, Frederico Westphalen, RS, Brasil e-mail: cantarelli@ufsm.br

\section{REFERENCES}

Araújo MS, Della Lucia TMC, Souza DJ. Estratégias alternativas de controle de formigas cortadeiras. Revista Bahia Agrícola 2003 [cited 2019 May 17]; 6(1): 71-74. Available from: http://bit.ly/2QdcJPM

Buratto DA, Cardoso JT, Rolim FA, Reis Filho W. Avaliação dos danos causados por formigas-cortadeiras do gênero Acromyrmex (Hymenoptera) aos plantios de
Pinus taeda no planalto sul-catarinense. Floresta 2012; 42(4): 683-690. 10.5380/rf.v42i4.23710

Cantarelli EB, Costa EC, Pezzutti R, Oliveira LS. Quantificação das perdas no desenvolvimento de Pinus taeda após o ataque de formigas cortadeiras. Ciência Florestal 2008; 18(1): 39-45. 10.5902/19805098509

Della Lucia TMC. Formigas cortadeiras: da bioecologia ao manejo. Viçosa: Editora UFV; 2011.

Diehl-Fleig E, Droste A. Localização, morfologia externa e flutuações populacionais ao longo do ano de colônias de Acromyrmex heyeri (Hymenoptera: Formicidae). Anais da Sociedade Entomológica do Brasil 1992; 21(1): 21-27.

Elizondo MH. Actualización del inventario de plantaciones forestales de la provincia de Corrientes. Buenos Aires: Consejo Federal de Inversiones; 2015.

Hölldobler B, Wilson EO. The ants. Cambridge: Harvard University Press; 1990.

Loeck AE, Grürzmacher DD. Ocorrência de formigas cortadeiras nas principais regiões agropecuárias do estado do Rio Grande do Sul. Pelotas: Editora UFPel; 2001.

Nickele MA, Pie MR, Reis Filho W. Emigration of a colony of the leaf-cutting ant Acromyrmex heyeri Forel (Hymenoptera, Formicidae). Revista Brasileira de Entomologia 2012; 56(3): 385-386. 10.1590/S0085-56262012005000045

Nickele MA, Reis Filho W, Oliveira EB, Iede ET. Densidade e tamanho de formigueiros de Acromyrmex crassispinus em plantios de Pinus taeda. Pesquisa Agropecuária Brasileira 2009; 44(4): 347-353. 10.1590/S0100-204X2009000400003

Nickele MA, Reis Filho W, Oliveira EB, Iede ET, Caldato $\mathrm{N}$, Strapasson P. Leaf-cutting ant attack in initial pine plantations and growth of defoliated plants. Pesquisa Agropecuária Brasileira 2012; 47(7): 892-899. 10.1590/ S0100-204X2012000700003

Pérez SP, Corley JC, Farji-Brener AG. Potential impact of the leaf-cutting ant Acromyrmex lobicornis on conifer plantations in northern Patagonia, Argentina. Agricultural and Forest Entomology 2011; 13(2): 191-196. 10.1111/j.1461-9563.2010.00515.x

Pezzutti RV, Caldato SL. Sobrevivência e crescimento inicial de mudas de Pinus taeda L. com diferentes diâmetros do colo. Ciência Florestal 2011; 21(2): 355-362. $10.5902 / 198050983240$

Pezzutti RV, Fleig FD, Finger CAG, Schneider PR. Estudo e modelagem do crescimento em diâmetro de povoamentos de Pinus taeda L. submetidos a podas e desbastes na Argentina. Ciência Florestal 2016; 26(4): 1225-1237. $10.5902 / 1980509825113$

Reis Filho W, Iede ET, Nickele MA. Boas práticas de prevenção e controle de formigas cortadeiras do gênero Acromyrmex em Pinus. Colombo: Embrapa Florestas; 2011. Reis Filho W, Iede ET, Nickele MA, Caldato N, Ferreira AC. Reconhecimento dos danos causados por formigas cortadeiras 
do gênero Acromyrmex em plantios iniciais de Pinus taeda no sul do Brasil. Colombo: Embrapa Florestas; 2007.

Reis Filho W, Santos F, Strapasson P, Nickele MA. Danos causados por diferentes níveis de desfolha artificial para simulação do ataque de formigas cortadeiras em Pinus taeda e Eucalyptus grandis. Pesquisa Florestal Brasileira 2011; 31(65): 37-42. 10.4336/2011.pfb.31.65.37

Vasconcelos HL, Cherrett JM. Leaf-cutting ants and early forest regeneration in central Amazonia: effects of herbivory on tree seedling establishment. Journal of Tropical Ecology 1997; 13(3): 357-370. 10.1017/S0266467400010567
Vitorino MD, Dutra RN, Arenhardt TCP, Beal LC, Gonçalves AHM, Marquardt RT et al. Avaliação do uso de imidacloprid no controle de Acromyrmex spp. (Hymenoptera: Formicidae) em plantio de Pinus taeda. Floresta 2015; 45(1): 41-48. 10.5380/rf.v45i1.31912

Zolessi LC, Abenante YP. Las hormigas cortadoras del Uruguay (Hymenoptera: Formicidae). In: Berti Filho E, Mariconi FA, Fontes LR, editors. Anais do Simpósio sobre Formigas Cortadeiras dos Países do Mercosul; 1998; Piracicaba, São Paulo, Brasil. Piracicaba: Fundação de Estudos Agrários Luiz de Queiroz; 1998. p. 85-91. 